\title{
O039: Patient participation and performance feedback to improve hand hygiene adherence in the context of established multimodal hand hygiene promotion: initial results from a mixed- methods, cluster randomised trial
}

\author{
AJ Stewardson ${ }^{1 *}$, A Gayet-Ageron ${ }^{1}$, S Touveneau ${ }^{1}$, L Clack², M Schindler ${ }^{3}$, W Zingg ${ }^{4}$, M Bourrier ${ }^{3}$, D Pittet ${ }^{1}$, H Sax $^{2}$
}

From 2nd International Conference on Prevention and Infection Control (ICPIC 2013)

Geneva, Switzerland. 25-28 June 2013

\section{Introduction}

Hand hygiene $(\mathrm{HH})$ compliance amongst healthcare workers is widely recognised as a key intervention in infection control. Given HH compliance remains suboptimal despite standard multimodal promotion, there is an urgent need for evidence regarding the effectiveness of novel interventions.

\section{Objectives}

To investigate the impact of optimised performance feedback (PF) and patient participation (PP) on $\mathrm{HH}$ compliance in the setting of a well-established multimodal $\mathrm{HH}$ promotion program.

\section{Methods}

Single-centre, cluster-randomised controlled trial. After a 15-month baseline phase from April 2009, 66 wards were allocated by stratified randomisation to one of three arms during a 24-month intervention phase: control; PF; or PF+PP. Multimodal promotion continued in all three arms. PF was provided via cards, posters and emails. PP involved a partnership whereby healthcare workers and patients agree to remind each other to perform $\mathrm{HH}$. The primary outcome was $\mathrm{HH}$ performance measured using the WHO 'My 5 Moments' methodology and analysed using a mixed effect logistic regression model. Qualitative data was gathered by focus groups and interviews with healthcare workers.

\section{Results}

Twelve observers recorded 12,627 $\mathrm{HH}$ opportunities during 1,358 sessions. HH compliance was similar between arms at baseline and increased in all three arms during the intervention phase $(\mathrm{P}=0.04): 65 \%$ to $73 \%$, odds ratio 1.36 (CI95\% 1.17-1.59); $64 \%$ to $74 \%$, OR 1.59 (1.39-1.81); and 64\% to 76\%, OR 1.77 (1.54-2.04), respectively, in control, $\mathrm{PF}$ and $\mathrm{PF}+\mathrm{PP}$ arms. Only $\mathrm{PP}$ $+\mathrm{FB}$ showed a significant effect on $\mathrm{HH}$ compliance in our trial (OR 1.33, $\mathrm{P}=0.04)$, with PF alone not sufficient (OR 1.17, $\mathrm{P}=0.25$ ). Qualitative data showed that acceptance and implementation of PP was gradual, variable and primarily dependent on ward leadership. Exclusion from intervention arms motivated control wards to improve $\mathrm{HH}$ performance independently.

\section{Conclusion}

PP with PF may offer a means of improving $\mathrm{HH}$ compliance beyond standard multimodal promotion.

\section{Disclosure of interest}

None declared.

\section{Author details}

${ }^{1}$ The Univ. of Geneva Hosp. and Fac. of Medicine, Geneva, Switzerland. ${ }^{2}$ Univ. and University Hosp. of Zurich, Zurich, Switzerland. ${ }^{3}$ Univ. of Geneva, Geneva, Switzerland. ${ }^{4}$ University of Geneva Hospitals and Faculty of Medicine, Geneva, Switzerland. 
doi:10.1186/2047-2994-2-S1-039

Cite this article as: Stewardson et al:: 0039: Patient participation and performance feedback to improve hand hygiene adherence in the context of established multimodal hand hygiene promotion: initial results from a mixed-methods, cluster randomised trial. Antimicrobial Resistance and Infection Control 2013 2(Suppl 1):039.

Submit your next manuscript to BioMed Central and take full advantage of:

- Convenient online submission

- Thorough peer review

- No space constraints or color figure charges

- Immediate publication on acceptance

- Inclusion in PubMed, CAS, Scopus and Google Scholar

- Research which is freely available for redistribution

Submit your manuscript at www.biomedcentral.com/submit
C Biomed Central 